\section{Renewable Agriculture and \\ Food Systems}

\section{cambridge.org/raf}

\section{Editorial}

Cite this article: Graddy-Lovelace G, Diamond A, Ichikawa NF (2020). Contextualizing the Farm Bill: questions of food, land and agricultural governance. Renewable Agriculture and Food Systems 35, 352-357. https://doi.org/ $10.1017 /$ S 1742170520000125

Received: 21 February 2019 Revised: 29 January 2020

Accepted: 10 February 2020

First published online: 8 May 2020

\section{Key words:}

Farm Bill; agricultural governance; interdisciplinary; farm policy; food justice; land use

\section{Author for correspondence:}

Garrett Graddy-Lovelace, E-mail: Graddy@ american.edu

\title{
Contextualizing the Farm Bill: questions of food, land and agricultural governance
}

Garrett Graddy-Lovelace ${ }^{1}$ (D) Adam Diamond ${ }^{2}$ (D) and Nina F. Ichikawa ${ }^{3}$

${ }^{1}$ School of International Service, American University, 4400 Massachusetts Avenue, Washington DC 20016, USA;

${ }^{2}$ Independent researcher and ${ }^{3}$ Berkeley Food Institute, UC Berkeley, Berkeley, CA, USA

\section{Introducing the Farm Bill}

The United States Farm Bill is a sprawling, complex piece of omnibus legislation flying largely under the public radar. It influences eaters, growers, land and water, rural, urban and suburban communities alike, across the country and across the world. Its vast purview covers everything from land use to food assistance, forestry to crop insurance and research to civil rights. Though the percentage of Americans making a living farming has never been lower, arguably, the number of people (domestic and international) impacted by the Farm Bill has never been greater as US exports at prices below the cost of production and food aid impacts millions of farmers globally (Murphy and Hansen-Kuhn, 2020). However, few know its cryptic language of acronyms and numbered short-hands that fill all 800+ pages (Ichikawa, 2013; Johnson and Monke, 2013; Mercier, 2016).

In December 2018, the Agricultural Improvement Act of 2018 ('The Farm Bill') was passed. Was this passage a feat of bipartisan governance-or proof of its wasteful, dysfunctional ways? Or both. Did it produce a lifeline for struggling farmers and hungry families-or a tangled mess of band-aids masking systemic crises? Or both. More research, analysis and dialogue are needed.

It was completed almost on time, less than 3 months after the 2014 Farm Bill expired. Amidst unprecedented partisan rancor, a budget fight that promptly led to a government shutdown, and a farmer income crisis, a largely status quo farm bill went through (Chite 2014; Hamilton, 2014; Orden and Zulauf, 2015). Though a feat of bipartisan policy-making, albeit with single-party control of the executive and legislative branches of government, this omnibus achievement garnered scant media interest. Ironically, the proposed cuts to the Supplemental Nutrition Assistance Program (SNAP), the one issue that received substantial media attention, were excised from the bill that reached the final passage, only to be repackaged and pushed through administratively the same day of the bill's signing.

What did the 2018 Agricultural Improvement Act actually accomplish in a time of deep economic struggle and precarity for farmers, ranchers, fishers and farmworkers? According to USDA ERS forecasts in early 2020, median farm income earned by farm households increased in 2019 to $-\$ 1,383$ from $-\$ 1,735$ in 2018 but was expected to decline to $-\$ 1,840$ in 2020. This was before the COVID-19 pandemic and subsequent financial disruptions (USDA ERS, 2020). The 2018 Farm Bill did launch the Farmer and Rancher Stress Assistance Program to address the emotional toll of high debt loads and (not) making a living on the land, and expanded crop insurance with enhanced Whole Farm Revenue Protection and localized Risk Management. However, the very causes of farm vulnerability, from the economic to the ecological, were largely unaddressed. The 2014 Farm Bill's $\$ 6$ billion in cuts to Conservation Title programs were not restored, but nor were they compounded. Even the same twelve title names and order were kept. In many respects, the 2018 Farm Bill made no sudden moves, for better or for worse.

We are deliberately publishing this novel set of papers examining the Farm Bill in Renewable Agriculture \& Food System, a journal committed to exploring food and agriculture ecologies, economies and social dynamics, all within a systems-thinking framework. The Farm Bill's structure attests to the fact that nutrition and soil conservation are inextricably related in a much larger system of production, distribution and consumption, and need to be governed and analyzed as such. Moreover, the term 'renewable' encompasses the urgency of Farm Bill logistics - it is iterative, being passed every 5 to 7 years. Failing to reach consensus on federal agricultural policy jeopardizes whole programs and projects. At its best, Farm Bill governance aspires to sustainable, resilient agri-food systems.

\section{Studying the current Farm Bill}

Despite growing interest in the Farm Bill among food movement activists and practitioners, it remains largely neglected and misunderstood in mainstream journalism and politics. Scholars 
have investigated various aspects of agricultural policy from across the social and natural sciences, but rarely have they analyzed the US Farm Bill itself as both a political process and policy product. This themed issue explores the ongoing tensions in Farm Bill debates and the outcomes of diverse constituencies advancing seemingly contradictory or disconnected goals. The Farm Bill both weaves a diverse array of social, economic, environmental and health concerns into one piece of uber-legislation, and represents the epitome of log rolling and political legerdemain as coalitions, interests, classes, and constituencies educate, bargain and lobby to advance their agendas. This compendium of multidisciplinary articles seeks to help transcend false binaries such as urban vs rural, 'farm subsidies' (NFFC, 2007; Schaffer et al., 2012; Graddy-Lovelace and Diamond, 2017) vs 'food stamps' (Wilde, 2013), yield $v s$ sustainability, and domestic $v s$ international farmers. While its authors may diverge in their analyses, as a whole this forum helps chart a course towards a food, farming and land-use policy that is just, viable, ecological and healthy.

This themed issue emerged out of a 2017 public symposium on the Farm Bill held at American University and co-sponsored by the Berkeley Food Institute. Speakers at this event and several others contributed research articles, commentaries and fora on topics ranging from nutrition to conservation policies, commodity subsidies and trade. We sought to look anew at common debates around its effectiveness as well as fairness, consider its global reach, and attempt to predict changes on the horizon. The authors in this transdisciplinary conversation include longtime experts with deep insider knowledge of the Farm Bill, distinguished scholars, graduate students, advocates and community organizers. We seek to bring these varying perspectives in conversation with each other, and with readers who will respond and debate these ideas from their lecture halls, Congressional offices, meeting rooms and milking parlors.

\section{Contextualizing the Farm Bill}

The Farm Bill first originated in the 1930s as the Agricultural Adjustment Act, but expanded to its modern form in the 1970s, when all the nutrition programs were combined with all of the farm programs into one omnibus package. This pairing of programs primarily addressing rural constituencies with programs focused mostly on urban constituencies produced a powerful coalition to support the Farm Bill, with rural and urban legislators united around a legislative package that had 'something for everyone.' For 40 years this bi-partisan political bargain has largely held up, even as the urban-rural split overlays a Democrat/ Republican division in political representation in many regions. However, the proposed delinking of the Nutrition Title from the rest of the Farm Bill for the past two Farm Bills has been a major stumbling block to negotiations (Bosso, 2017).

More analysis is needed on the nuances of the Farm Bill itself, from its origins and negotiations to its multifaceted social, ecological, political and economic impacts (Clark et al., 2015). The legislation-and thus the scholarship on it-must address current trends, from food regionalization (Low et al., 2015) to the rise of urban producers and farmers markets (Dimitri et al., 2015), and shifting legal context for farmers navigating rapid systems change (Hipp and Francis, 2005) It needs to respond to the volatile and growing impacts of climate change, water scarcity and other ecological phenomenon on agricultural production (UNCTAD, 2013), as well as address the century-long-tension between conservation and production (Reimer and Linda, 2014) and more recent endeavors such as grain perennialization (Jackson and Berry, 2010). Due to its foundation in 1930s and 1940s 'permanent law' and the global economic crisis that was the Great Depression it needs historical and geopolitical contextualization. The articles in this issue provide an important layer of contextualization to agricultural governance in the U.S., more is needed, but this provides a foundation.

As a long and complicated tome comprised self-references, it demands public scholarship to allow informed public debate and civic engagement. Moreover, it must acknowledge the dynamics of racism, sexism and other axes of discrimination in US agricultural policy, and community-led initiatives working to overcome them (White 2011; Doan-Crider et al., 2013; Graddy-Lovelace, 2016; Fagundes et al., 2020). This themed issue examines major Farm Bill issues with an eye to their oversights and path dependencies (Dimitri and Effland, 2020): nutrition programs (Gosliner and Shah, 2020; Pino, 2019), farm safety nets (Zulauf, 2019), conservation programs serve as band-aids to larger, structural crises of food insecurity (Anderson, 2020; Bellows, 2020; Riches, 2020), farmer inviability (Ray and Schaffer, 2008, Schaffer and Ray, 2020), rural community struggles (Labao and Moyer, 2001) and ecological exhaustion (Fagundes et al., 2020). Rhetoric of 'national interest' is used for myriad policy goals across multiple Farm Bills (Lehrer, 2020). While U.S. agricultural policy has long served as a driver of geopolitical power dynamics (Winders, 2020), trade becomes even more of a flashpoint for international tensions (Hansen-Kuhn, 2011, Wise, 2009).International agricultural aid to lift up the economies of developing nations could serve as an escape valve from seemingly intractable conflicts over trade barriers (Mercier, 2020).

\section{Reading the Farm Bill: major themes and titles}

\section{Commodity policy and crop insurance}

The past four decades of federal farm policy has seen a general shift away from supporting farm commodity prices with commodity reserves, marketing quotas and acreage restrictions to a more laissez-faire approach, with subsidy payments functioning as the primary farm safety net (Bowers et al., 1984). Winders, (2009) chronicles the domestic power dynamics at work in US farm policies enabling commodity crop (over)production. And, in the last two decades commodity program payments have given way to crop insurance subsidies as the primary safety net mechanism (Zulauf et al., 2016). The move to crop insurance reflects increasing political hostility to 'subsidies' as a form of welfare or undeserved assistance; instead, government subsidies for crop insurance premiums are framed as a market oriented risk management policy that buffers the effects of market volatility while ensuring that farmers respond to price signals and not to government program payments in their planting decisions (Gardner, 2006). Subsidies for crop insurance also serve to bypass discussion of payment limits for commodity programs. In 'U.S. Commodity Policy: Evolution, Experiments, Constants, and Implications,' Zulauf (2019) gives a historical survey of the Commodity Title, tracing its evolution as a series of policy experimentations with countercyclical and direct payments; he culminates his overview with reflections on how the Commodity Title's original risk management goals have moved over to crop insurance and crop insurance supplements. The Farm Bill's central mandate as a safety net has persisted, amidst vast changes in how this safety net has been 
envisioned and implemented. Zulauf suggests viewing these evolutions commodity-by-commodity, with specific focus on how each commodity crop has made its way through the various swings from production controls to base-acre-based payments. On the other hand, in their article 'Agricultural Supply Management and Farm Policy,' Schaffer and Ray (2020) explore the root causes of why safety nets are so needed and yet so fraught. They trace this policy conundrum back to agriculture's chronic price and income problems: the tendency to overproduce commodity crops and lack of effective market responsiveness in the very structure of farm economics. Their research leads squarely back to the question of supply management, so foundational to the history of the Farm Bill, and yet so forgotten in its demise over the past generation. Schaffer and Ray conclude their extensive analysis with an important proposal for a 21 st century version of supply management programs based in market driven inventory systems to balance and coordinate supply with demand.

\section{Conservation title}

For nearly a century, the Conservation Title has directly and dutifully followed the Commodity Title. In the throes of the Dust Bowl and Depression, farmers trekked to Washington to demand government assistance. Farmers were acutely aware of the twin ecological-and economic-crises of commodity crop overproduction. The 1938 Agricultural Adjustment Act foregrounded soil conservation alongside supply management. For decades, farmers were given soil conservation assistance and by the 1980s programs such as the Conservation Reserve Program (CRP) put highly erodible land out of production. By the 2002 Farm Bill, Working Lands programs gained ground to help farmers implement biodiversity and conservation practices on land in production, though agro-fuel incentives brought a range of domestic and international issues (Lehrer, 2010) In addition to the popular Environmental Quality Incentives Program (EQIP), farmers, ranchers and forested landowners could sign up for the Conservation Stewardship Program (CSP) to design and implement more integrative and long-term ecological practices on their lands. Though voluntary and under-funded, Conservation Title programs continue to anchor the Farm Bill. In their article, 'Ecological Costs of Discrimination: Racism, Red Cedar, and Resilience in Farm Bill Conservation Policy in Oklahoma,' Fagundes et al., document however how such conservation programs and policies have suffered from structural racism and biases and historically underserved farmers and ranchers of color (Fagundes et al., 2020). This article emerged from a communitypartnered action research project (and thus is co-authored) with American University students and faculty and long-time leaders and practitioners within the community-based organizations the Rural Coalition and the Oklahoma Black Historical Research Institute, that works with farmers and ranchers of color in Oklahoma to support African-American and indigenous agriculture and communities. This research maps and contextualizes the ways invasive species have pervaded the landscape and jeopardized waterways and arable and grazing land throughout the state, while Natural Resources \& Conservation Service resources to mitigate the problem have disproportionately been accessed by white landowners. The paper argues that systemic racism persists in the USDA Conservation Title programs and how it hurts farmers and ranchers of color so acutely, but ultimately also: people, land, waterways, firescapes and climates more broadly. The paper concludes with instances of how grassroots community- based organizations are instrumental to farmers and ranchers of color in accessing and making use of Conservation Title programs-and thus their important potential for countering discrimination and injustices in agriculture and for supporting equitable climate-resilient land use in general.

\section{Trade}

Trade is seen as an outlet for commodity surpluses that can reduce government expenditures on farm programs while helping to increase commodity prices and thus support farm income. Murphy and Hansen-Kuhn (2020) examine the history and politics of dumping of agricultural commodities. For the last 20 years the U.S. has consistently sold agricultural products on international markets below the cost of production. This process has been facilitated in part by domestic subsidy programs that allow farmers to continue farming even when the market price is lower than production costs, However. It is critical to account for the influence of agribusiness oligopolies on commodity prices, and the degree to which they engage in futures trading to manipulate price shifts for maximum advantage, undercutting the stated purpose of futures trading as a hedge against price volatility.

Stephanie Mercier with 'Adding a New Perspective to U.S. Agricultural Policy' (Mercier, 2020) provides an alternative perspective to debates over the merits of free trade. Mercier suggests that too much attention is paid to opening up mature developed country markets to U.S. agricultural exports, at the expense of rapidly growing developing country export markets. U.S. policy makers should focus on increasing demand in developing countries by helping the agricultural sectors of these countries grow, as they constitute the largest sectors of their economies. The lesson here would seem to be a rising tide lifts all boats, from Ghanian smallholders to Kansas wheat farmers.

Bill Winders, in 'The Global Context of the US Farm Bill in 2018: World Markets, Instability, and Policy Preferences in Agriculture' (Winders, 2020) examines the impact of global demand, international competition and price instability on the policy preferences of different blocks in American agriculture. Winders predict that feed grain farmers will oppose production controls and trade restrictions, while wheat farmers, facing more competition and weaker demand than feed grain farmers will be more open to grain reserves as a way to moderate price volatility. Overall, Winders links changes in policy preferences among farm groups to the global market, and bases his analysis of future policy preferences accordingly. He provides a sober examination of why certain farm groups are likely to have certain policy preferences.

Nadine Lehrer, in 'US Farm Bills and the National Interest: An Historical Research Paper' (Lehrer, 2020) looks at how the changing role of national interest discourse is mobilized to justify diverse policy goals in Farm Bill statutory language. Overall, the general trend is that of a shift from purely domestic concerns to more international ones. And invocations of national security correspond to periods when the national mood was one of vulnerability to external threats, whether that be the Cold War in the 1980 s or terrorism in the wake of the $9 / 11$ attacks.

With the government now focused on renegotiating unfair trade deals, the positioning of the U.S. as vulnerable to outside economic threats has been employed to justify protectionist policies. Yet farm interest groups have a strong pro-export orientation for the most part. The NAFTA renegotiations led to some concessions by Canada giving American dairy farmers more 
access to the Canadian market, but the end result was a loosening of trade restrictions, which was intended to benefit American producers. It's just that in this case a discourse of vulnerability rather than that of a rising tide lifts all boats was employed to basically force open the Canadian dairy market a bit.

\section{Nutrition}

The Nutrition Title is the spending behemoth of the Farm Bill, and remains one of the most contentious, with critics demanding restrictions to avoid spending money on the 'undeserving' and supporters arguing for increased benefit levels and the elimination of bureaucratic obstacles to signing up for benefits. Molly Anderson, in 'Make federal food assistance rights-based' (Anderson 2013, 2020) proposes a paradigm shift to shake up the debate over whether or not recipients of programs like SNAP are 'deserving.' The US is the only industrialized country in the world that does not formally accept food as a human right, which Anderson traces to the Cold War-driven impulse of the US to support political and civil rights of individuals but not economic, social and cultural rights (including the right to food). Her grounding in our legal and moral obligations, and responses by Bellows and Riches (Bellows, 2020; Riches, 2020) lay important groundwork for the perspectives from the field offered by Pino, Gosliner and Shah.

Lisa Pino, in 'Immigration Policy and Perception Impacts on SNAP Access and Eligibility: A View from the Field,'(Pino, 2019) gives an insider's perspective on Farm Bill implementation with a special focus on limited-English speakers and non-citizen SNAP recipients. These 'liminal citizens' (Torres and WicksAsbun, 2014) face de facto and de jure obstacles to receiving needed food aid, resulting in a staggering rate of Latino food insecurity rate of $26.9 \%$ in 2009 (almost double the national average of $14.7 \%$ ), and making cultural competence in nutrition outreach and assistance that much more pertinent.

In 'Participant Voices: Examining Issue, Program, and Policy Priorities of SNAP-Ed Eligible Adults in California,' (Gosliner and Shah, 2020) the authors looked closely at a sample of recipients of this nutrition education program, estimated to spend $\$ 428$ million nationally in FY 2019. Among families sampled across five California counties, the authors found that low-income parents generally understood what to feed their children, but faced structural barriers (primarily financial) to acquiring sufficient healthy food. Gosliner and Shah argue that a 'deeper understanding of the interplay between structural constraints, social support, and agency is needed to identify optimal solutions.'

A few common themes emerge from these three very different contributions related to the Nutrition title. One is the racialized nature of food assistance in the U.S. In her case for a rights-based approach to food assistance, Anderson compares the stigmatization of SNAP recipients (often portrayed, inaccurately, as primarily non-white) with the lack of stigma associated with the federal tax deduction for mortgage interest. Noting that the latter accrues disproportionately to whites and increases with rising incomes, the total expense of both programs was approximately the same in 2016 ( $\$ 70$ billion each).

Another key theme is how nutrition assistance recipients need to be able to inform, and influence how the programs are run. When Gosliner and Shah based their study on 'participant voices,' they discovered nuances of nutrition education and policy implementation that would have been difficult to predict in the sterile laboratories of policy development. Policymakers would do well to be informed by these voices and their valuable direct experience with Farm Bill nutrition programs.

\section{From miscellaneous to mandatory}

They have been called 'tiny but mighty'(National Sustainable Agriculture Coalition, 2018) - the basket of smaller Farm Bill programs that were established to address inequities among American farmers, farming styles, land tenure arrangements and even data itself. Falling under the $\$ 50$ million 'baseline' funding level since their inception, many of these programs were awarded baseline funding for the first time in the 2018 Farm Bill. What does that mean for their political power? With growing market share and now official endorsement in the form of permanent Farm Bill programs, should farmers who benefit from these programs (many of whom fall under the rubric of 'alternative farming') now call for concomitant lower funding for so-called 'conventional farming'? Food hubs have emerged and expanded across the country (Diamond and Barham, 2011), as have 'local,' organic and direct-to-consumer marketing, but most Farm Bill funding continues to support industrialized monocropping, not diverse agri-food systems and marketing channels. In their article, 'From farming to food systems: The evolution of U.S. agricultural production, and policy into the 21 st Century,' Dimitri and Effland (2020) provide a valuable overview of major transitions in U.S. agriculture, and the economic, ecological and social implications for the vast changes over the past few generations. They explore the tension between the continued focus of Farm Bill programs on conventional field crop farming, and the growing support for organic research and extension, and local food marketing. Their paper ends with recommendations for how Farm Bill policies and paradigms could be updated and expanded to better respond to and facilitate efforts to regionalize and localize food systems for more resilient and sustainable agri-food systems.

The 2018 Farm Bill includes important changes that increased support for local agriculture, beginning farmers and racial justice; namely the creation of the Local Agriculture and Market Promotion and Farmer Outreach and Training Opportunities (FOTO) programs. The former combines the Value-Added Producer Grant Program and the Farmers Market and Local Food Promotion Programs into one larger program that receives baseline funding of $\$ 50$ million a year. Likewise, FOTO combines the 2501 Program for Socially Disadvantaged Farmers and Ranchers with the Beginning Farmers and Ranchers Program, also creating baseline funding of $\$ 50$ million a year. In both cases the baseline funding designation means that future farm bills will include these programs by default, unless steps are taken to remove them.

Furthermore, the 2018 Farm Bill included 63 new provisions to support and advance indigenous agriculture and tribal producers, food providers and communities. The newly formed Native Farm Bill Coalition built upon previous alliances and networks: the Coalition describes itself as 'a joint project of the Shakopee Mdewakanton Sioux Community's Seeds of Native Health campaign, the Intertribal Agriculture Council, the National Congress of American Indians, and the Indigenous Food and Agriculture Initiative to improve Native dietary health and food access.' As of late 2019, it listed 77 tribes and multiple inter-tribal groups and Native organizations as members.

Despite the length and breadth of the Farm Bill, however, so much is left out altogether. From immigration and labor, to antitrust enforcement, from fisheries to antibiotics and public health. 
Food provisioning for low-income communities is split between the Farm Bill and Child Nutrition Reauthorization, leading to confusion. Food safety and environmental health related to agriculture are further areas of bisected jurisdiction, threatening the federal government's ability to achieve regulatory coherence. More education is needed for citizens to better understand the possibilities and limitations of the Farm Bill's jurisdiction.

\section{Questions of food, land and agricultural governance}

At the heart of the Farm Bill inquiry is the question of effective, equitable governance. Does the Farm Bill's omnibus structure epitomize the strength or weakness of this legislation? And is it wise policy to incorporate land use and nutrition in the same bill, or mere political expediency? To what extent does the Farm Bill include the right policy areas at all, or is it a pathdependent amalgam of political convenience? Moving forward, Farm Bill scholarship needs to address the question of scale of governance more directly: What is the relationship between federal policy and state, regional, municipal and county policymaking and policy-implementing? What forums exist for such conversation, analysis, delegation and collaboration? What about the vast international impacts of the U.S. Farm Bill-in and beyond the Trade Title? How does this intricately national and historically nationalist/nation-building legislation relate to World Trade Organization paradigms and paradoxes? What would a forum look like whereby farmers and frontline farmer organizations from around the world can share their experiences on the impacts of Commodity and Research and Trade and food aid programs and priorities?

While beyond the scope of this themed issue, it is critical to acknowledge how policy questions that have been central points of debate in Farm Bills are now being decided by executive action, outside the legislative process that heretofore has governed the Farm Bill. The USDA just launched another round of payments to farmers to offset trade losses: $\$ 16 \mathrm{~B}$ on top of the $\$ 12 \mathrm{~B}$ in 2018, along with massive payments in the COVID-19 federal aid package. Meanwhile, the USDA released a proposed rule cutting SNAP eligibility for 3.1 million people in order to save $\$ 25 \mathrm{~B}$ over a decade. Yet, SNAP rules and direct payments to farmers have historically been part of the Farm Bill negotiations and authorizations. This overriding of legislative deliberation and oversight begs urgent questions about the nature and dynamics of agricultural governance at large. In short: more research is needed on the content and process of the Farm Bill-and beyond.

How do we expand and deepen public, civic scholarship and dialogue on the Farm Bill while also contextualizing it within the broader complexities and urgencies of agricultural governance at large? If what we used to think of as the scope of the Farm Bill is now subordinated to executive action, then people concerned about food and farm policy need to be even more vigilant about the myriad pathways governance manifests, and create more opportunities for diverse constituencies-from farmers, to SNAP recipients to scholars and activists and policy makers-to learn from each other. Agricultural and food governance at a basic level cuts to the core functions of states-providing for the subsistence needs of their citizens, regulating land use and protecting economic producers against catastrophe and economic turbulence. In unpacking the Farm Bill as a policy process and policy object we are addressing existential questions of governance writ large.

More research is needed on this complex piece of omnibus legislation. Practitioners (farmers, ranchers, farmworkers, fishers and seed-savers) talking with soil scientists, agricultural economists debating with historians, anti-hunger advocates working with anti-racist scholars, cooperative extension agents and policymakers (from Congressional Agricultural Committees to local food policy councils). We hope this compilation of articles and essays helps advance the broader conversation-across and beyond academic disciplines-on the importance of Farm Bill assessment, analysis, debate and dialogue to help inform, reform and transform food, land and agricultural policy for a more equitable, viable and resilient agri-food system at large.

Acknowledgement. We wish to acknowledge all the myriad contributors to this special issue, with a particular thanks to those practitioners from the field who took time from their work to translate their findings into articles. We wish to also thank all the speakers and attendees at 'Farm Bill 2018: Policy, Politics, and Potential,' a public symposium held on March 28, 2017 at American University in collaboration with the Berkeley Food Institute. This special issue grew out of that symposium, which sought to inform, reform and transform the Farm Bill through community-partnered research.

\section{References}

Anderson MD (2013) Beyond food security to realizing food rights in the US. Journal of Rural Studies 29, 113-122.

Anderson MD (2020) Make federal food assistance rights-based. Renewable Agriculture and Food Systems 35, 439-441.

Bellows AC (2020) A systems-based human rights approach to a national food plan in the USA. Renewable Agriculture and Food Systems 35, 442-444.

Bosso CC (2017) Framing the Farm Bill: Interests, Ideology, and the Agricultural Act of 2014. Lawrence, KS: University Press of Kansas.

Bowers D, Rasmussen W and Baker G (1984) History of Agricultural Price-Support and Adjustment Programs, 1933-1984. Economic Research Service, US Department of Agriculture. Agricultural Information Bulletin No. 485. December.

Chite RM (2014) The 2014 Farm Bill (P.L. 113-79): Side-by-Side. Congressional Research Service. Washington D.C. 12 February, pp. 1-235.

Clark J, Sharp JS and Dugan KL (2015) The agri-food system policy agenda and research domain. Journal of Rural Studies 42, 112-121.

Diamond A and Barham J (2011) Money and mission: moving food with value and values. Journal of Agriculture, Food Systems and Community Development 1, 101-117.

Dimitri C and Effland A (2020) From farming to food systems: the evolution of US agricultural production and policy into the 21st century. Renewable Agriculture and Food Systems 35, 391-406.

Dimitri C, Oberhotlzer L, Zive M and Sondolo C (2015) Enhancing food security of low-income consumers: an investigation of financial incentives for use at farmers markets. Food Policy 52, 64-70.

Doan-Crider D, Hipp JS, Fight LL, Small V and Small VY (2013) Keeping native American communities connected to the land: women as change agents. Rangelands 35, 63-67.

Fagundes C, Mleczcko J, Picciano L, Tillman W, Graddy-Lovelace G, Schwier S, Hal F and Watson T (2020) Ecological costs of discrimination: Racism, Red Cedar, and Resilience in Farm Bill Conservation Policy in Oklahoma. Renewable Agriculture and Food Systems 35, 420-434.

Gardner B (2006) American Agriculture in the 20th Century: How It Flourished and What It Cost. Cambridge: Harvard University Press.

Gosliner W and Shah H (2020) Participant voices: examining issue, program, and policy priorities of SNAP-Ed eligible adults in California. Renewable Agriculture and Food Systems 35, 407-415.

Graddy-Lovelace G (2016) The coloniality of US agricultural policy: articulating agrarian (In)Justice. Journal of Peasant Studies 43, 1-22.

Graddy-Lovelace G and Diamond A (2017) From supply management to agricultural subsidies-and back again? US farm bill \& agrarian (In) Viability. Journal of Rural Studies 50, 70-83.

Hamilton N (2014) The 2014 farm bill: lessons in patience, politics and persuasion. Drake Journal of Agricultural Law 19, 1-37. 
Hansen-Kuhn K (2011) Making U.S. Trade Policy Serve Global Food Security Goals. Institute for Agriculture \& Trade Policy.

Hipp J and Francis H (2005) The legal environment facing economic agents in production. Journal of Agricultural and Applied Economics 37, 327-337.

Ichikawa NF (2013) Why City Slickers Should Care About the Farm Bill. Al-Jazeera America. 4 December.

Jackson W and Berry W (2010) The Fifty Year Farm Bill. Kansas: The Land Institute.

Johnson R and Monke J (2013) What is the farm bill? Current Politics and Economics of the United States 15, 413-426.

Lehrer N (2010) US Farm Bills and Policy Reforms: Ideological Conflicts Over World Trade, Renewable Energy, and Sustainable Agriculture. Amherst: Cambria Press.

Lehrer N (2020) US Farm bills and the 'national interest': an historical research paper. Renewable Agriculture and Food Systems 35, 358-366.

Lobao L and Moyer K (2001) The great agricultural transition: crisis, change, and social consequences of twentieth century US farming. Annual Review of Sociology 27, 103-124.

Low SA, Adalja EB, Key N, Martinez S, Melton A, Perez A, Ralston K, Stewart H, Suttles S, Vogel S and Jablonski BBR (2015) Trends in U.S. Local and Regional Food Systems, AP-068, U.S. Department of Agriculture, Economic Research Service.

Mercier S (2016) The Making of a Farm Bill. Choices. Quarter 3. Available at http://www.choicesmagazine.org/choices-magazine/submitted-articles/ the-making-of-a-farm-bill.

Mercier S (2020) Adding a new perspective to US agricultural trade policy. Renewable Agriculture and Food Systems 35, 445-448.

Moore J (2015) Capitalism in the Web of Life: Ecology and the Accumulation of Capital. New York: Verso Books.

Murphy S and Hansen-Kuhn K (2020) The true costs of US agricultural dumping. Renewable Agriculture and Food Systems 35, 376-390.

National Sustainable Agriculture Coalition (2018) What's at Stake: Tiny but Mighty Farm Bill Programs. September 4. Available at http://sustainableagriculture.net/blog/tiny-but-mighty-farmbill-series/.

NFFC (National Family Farm Coalition) (2007) Food from Family Farms Act: A Proposal for the 2007 US Farm Bill, pp. 1-8.

Orden D and Zulauf C (2015) Political economy of the 2014 farm bill. American Journal of Agricultural Economics 97, 1298-1311.

Pino L (2019) Immigration Policy and Perceptions Impacts on SNAP Access and Eligibility: A View from the Field. Renewable Agriculture and Food Systems, TBD.
Ray, DE and Schaffer, HE (2008) Agriculture of the middle: lessons learned from civic agriculture. In Thomas Lyson GW Stevenson RW and Guptill A (eds), In Food and the Mid-Level Farm: Renewing An Agriculture of the Middle. Cambridge: MIT Press.

Reimer A and Linda SP (2014) Farmer participation in the U.S. Farm Bill Conservation Program. Environmental Management 53, 318-332.

Riches G (2020) The right to food, why US ratification matters. Renewable Agriculture and Food Systems 35, 449-452.

Schaffer HD and Ray DE (2020). Agricultural supply management and farm policy. Renewable Agriculture and Food Systems 35, 453-462.

Schaffer H, Hellwinckel C, Ray D and Ugarte D (2012) An Analysis of Market-Driven Inventory System. Agricultural Policy Analysis Center. University of Tennessee Institute of Agriculture, pp. 1-72.

Torres MT and Wicks-Asbun M (2014) Undocumented students' narratives of liminal citizenship: high aspirations, exclusion, and "In-between" identities. The Professional Geographer, 195-204.

UNCTAD (United Nations Conference on Trade and Environment) (2013) Wake Up Before It Is Too Late: Make Agriculture Truly Sustainable Now for Food Security in a Changing Climate.

USDA ERS (2020) https://www.ers.usda.gov/topics/farm-economy/farmsector-income-finances/highlights-from-the-farm-income-forecast;.

White M (2011) D-Town farm: African American resistance to food insecurity and the transformation of Detroit. Environmental Practice 13, 406-417.

Wilde P (2013) Food Policy in the United States: An Introduction. London: Earthscan Food \& Agriculture.

Winders B (2009) The Politics of Food Supply: US Agricultural Policy in the World Economy. New Haven: Yale University Press.

Winders B (2020) The global context of the U.S. farm bill in 2018: world markets, instability, and policy preferences in agriculture. Renewable Agriculture and Food Systems 35, 367-375.

Wise T (2009) Promise or pitfall? The limited gains from agricultural trade liberalisation for developing countries. Journal of Peasant Studies 36, 855-870.

Zulauf C (2019) U.S. Commodity policy: evolution, experiments, constants, and implications. Renewable Agriculture and Food Systems.

Zulauf C, Schnitkey G, Coppess J and Paulson N (2016) Farm Payments by Countercyclical and Insurance Programs Since 2002. farmdoc daily. 6:230. Department of Agricultural and Consumer Economics, University of Illinois at Urbana-Champaign. 8 December. 